SHS Web of Conferences 2, 00014 (2012)

DOI: $10.1051 /$ shsconf/20120200014

(C) Owned by the authors, published by EDP Sciences, 2012

\title{
Evaluation of the activity of the child welfare commission in pursuance of the minimal care of the child
}

\author{
V. Indrasiene and O. Merfeldaite \\ Mykolas Romeris University, Lithuania
}

\begin{abstract}
The Law on Minimal and Average Care of the Child of the Republic of Lithuania (in effect since 1 January 2008) established the procedure for provision of minimal and average care for the child having behavioural problems and susceptible to crime. The article analyses activities of child welfare commission in implementing the minimal care of the child: the first part of the article provides a description of the concept of minimal care of the child and the responsibilities of implementing institutions; the second part analyses obstacles in implementing the law and envisages possible measures for a more effective activity of preventive work groups in municipalities and schools.
\end{abstract}

Key words: child, minimal child care, juvenile justice, child welfare commission

Antisocial behaviour of children is one of the biggest problems of a contemporary family, school and every member of the society. Juvenile delinquency is in some way the beginning of general criminality, its potential reserve and at the same time a forecast of future trends. Pursuant to the Juvenile Justice Programme for 2009-2013, juvenile law offences are the beginning of adult criminal activity.

With a view to implementing the Juvenile Justice Programme, the Law on Minimal and Average Care of the Child of the Republic of Lithuania (in effect since 1 January 2008, Official Gazette, 200707-19 No 80-3214; 2010-12-14, No 157-7969) established the procedure for provision of minimal and average care of the child, the principles and measures of average care, the background and the procedure for allocation, extension, replacement and elimination of these measures, and provisions for application of medium child care measures in child socialisation centre.

In order to ensure implementation of provisions of the United Nations Convention on the Rights of the Child (Official Gazette, 1985, No 60-1501), the Havana Rules (1990) and the Riyadh Guidelines (1990) declaring the freedom of the child or, in case of deprivation of freedom, integration of the child into society, efforts of the community members in assuring individual support for the child and family are instrumental. Positive practice of the European Juvenile Justice also highlights the importance of the involvement of community, and specifies three main operational spheres of community: prevention, pedagogical education, social and professional integration (Opinion of the European Economic and Social Committee for the Prevention of Juvenile Delinquency. Ways of Dealing with Juvenile Delinquency and the Role of the Juvenile Justice System in the European Union (2006/C 110/13). Thus, prevention is the task of communities which have to join and co-ordinate efforts of concerned institutions (non-governmental organisations, public and municipal institutions, agencies, enterprises and other organisations). However, because of complex cases in Lithuania requiring the assistance for the child and family, there is still lack of a clear scheme of activities of institutions and agencies, as well as a clear distribution of responsibilities among different agencies on coordination of provision of complex assistance in cases of the minimal care. Relevant regulatory enactments oblige providers of education, social and legal services to join the cooperation network. However, so far the information exchange and cooperation is executed only between stakeholders of a particular sphere and

This is an Open Access article distributed under the terms of the Creative Commons Attribution License 2.0, which permits unrestricted use, distribution, and reproduction in any medium, provided the original work is properly cited. 


\section{SHS Web of Conferences}

is based on personal contacts. The data about children is accumulated in target databases of relevant institutions, and agencies and other institutions usually don't have access to this data.

Although usually responsibility for implementation and coordination of minimal care measures is delegated to school specialists, the measures and effectiveness of assistance are not yet consistently analysed at national level.

Object of the research: activity of the school and municipal child welfare commission in pursuance of the minimal care of the child.

Goal: to analyse the experience of the child welfare commission in implementing the measures for the minimal care of the child.

Tasks:

1) To discuss the assumptions for implementation of the minimal care of the child in Lithuania;

2) To analyse functions of the child welfare commission at municipal and school level;

3) To identify problems of the child welfare commission in implementing the minimal care of the child.

\section{Methodological provisions}

The article is based on the following documents: The Concept for the Establishment of Social Networks (Darling-Hammond, Laughlin, 1995) highlighting the importance of social networks for each participant of the education process; the systematic approach, according to which every person can grow and develop his/her skills only in interaction with the environment, subordination and harmony (Payne, 2000); the ecological model aimed at encouraging operations groups, organisational structures, social network and physical environment (Germain, Gitteman, 1980; Berns, 2009).

\section{Research methodology}

With a view to analysing operational aspects of the child welfare commission at institutional and municipal level, 114 members of municipal and school child welfare commissions were interviewed.

The research was carried out in three stages. The first stage included the analysis of the Law on Minimal and Average Care of the Child and the activity of child welfare commissions (pursuant to the operational trends stipulated in the Law). During the second stage the agreement was made with the members of child welfare commissions on the time of interview. The third stage included the acquaintance with respondents, presentation of the research results, and questions. The sequence of questions depended on the procedure of an interview with respondents and on their emotional state. The data was registered in special sheets (members of the group refused audio recording for the sake of their security). It was necessary to record the data in writing, since respondents" answers while discussing research results were interpreted separately by their job positions (audio record complicates identification of a speaker). The third stage included the data analysis and interpretation. Results of the interview were analysed by applying the method of content analysis (including identification of categories and subcategories). The accumulated research data was presented to the participants of the research. Reliability of the analysis was ensured by meeting requirements of the content analysis.

\section{Concept and implementation of the minimal care of the child}

The Law on Minimal and Average Care of the Child of the Republic of Lithuania (Official Gazette, 19 July, 2007, No 80-3214, Official Gazette, 14 December, 2010, No 157-7969) sets forth the procedure for the entitlement of the minimal and average care for children with behaviour problems or susceptible to crime. The Law establishes principles and measures for minimal and average care of the child; the 


\section{Int. Conf. SOCIETY. HEALTH. WELFARE; Congr. of Rehabilitation Doctors of Latvia}

background and the procedure for the entitlement, extension, replacement and elimination of these measures, as well as provisions for the application of average care for the child in children 's socialisation centres.

Minimal care of the child is perceived as an educational or other assistance to the child, as well as other services aimed at positive behaviour changes of children (Official Gazette, 19 July, 2007, No 80-3214, Official Gazette, 14 December, 2010, No 157-7969).

Pursuant to the provisions of the Law on Minimal and Average Care of the Child, minimal measures of the child care could be imposed on the child: 1) who commits an act with the marks of a criminal act or criminal offence but has not reached the legal age of responsibility set forth in the Criminal Code of the Republic of Lithuania; 2) who constantly commits the acts with the marks of administrative offence but has not reached the age set forth in the Code of Administrative Violations of Law of the Republic of Lithuania imposing administrative responsibility; 3) who committed an administrative offence, but, pursuant to the provisions of the Code of Administrative Violations of Law of the Republic of Lithuania, was not imposed an administrative penalty; 4) whose behaviour is detrimental and harmful to other people and efforts of local community are insufficient to reach positive changes in the behaviour; 5) who does not permanently attend compulsory education programmes (or does not attend school). These measures could be imposed only when a school has used all possibilities for provision of educational assistance stipulated in the Law on Education of the Republic of Lithuania. The tasks of minimal and average care of the child could be defined as a set of measures aimed at restricting, neutralizing or eliminating the circumstances stipulating negative socialization of an individual. Pursuant to the Law, responsibility for execution of measures of the minimal care is attributed to school and municipal child welfare commissions.

The purpose of the child welfare commission is to organise and coordinate preventive work and educational assistance, to create safe and favourable environment for the development of the child, and to perform other functions related to welfare of the child.

The purpose of the municipal child welfare commission is to coordinate implementation of educational, rehabilitation, preventive and other programmes in the territory of municipality, as well as inter-institutional cooperation in providing methodological, information, counselling and other assistance to school child welfare commissions.

In conclusion it may be stated that both municipal administration child welfare commission and child welfare commission perform two main functions: management and counselling; only the level of performance differs: school child welfare commission execute their activities at institutional and community level; municipal child welfare commission - at municipal and regional level. Therefore municipal administration child welfare commissions are oriented toward the situation in a specific municipality and long-term preventive measures, whereas school child welfare commission are more directed toward the establishment of short-term preventive measures at institutional and community level (Figure 1).

\section{Results: Evaluation of the activity of the child welfare commission}

According to all respondents, measures set forth in the Law on Minimal and Average Care of the Child help to ensure a qualified and child oriented assistance to the child and his/her family and develop relationship with the child's environment. Respondents identified the following main operational trends of the municipal child welfare commission: coordination of implementation of inter-institutional cooperation $(n=64)$; provision of methodological assistance to school child welfare commissions $(n=60)$. None of respondents identified provision of high quality social assistance to the child as the main function of the child welfare commission. The majority of respondents were of the opinion that functions of a municipal child welfare commission are more related to control and supervision. According to respondents, main functions of members of the municipal child welfare 


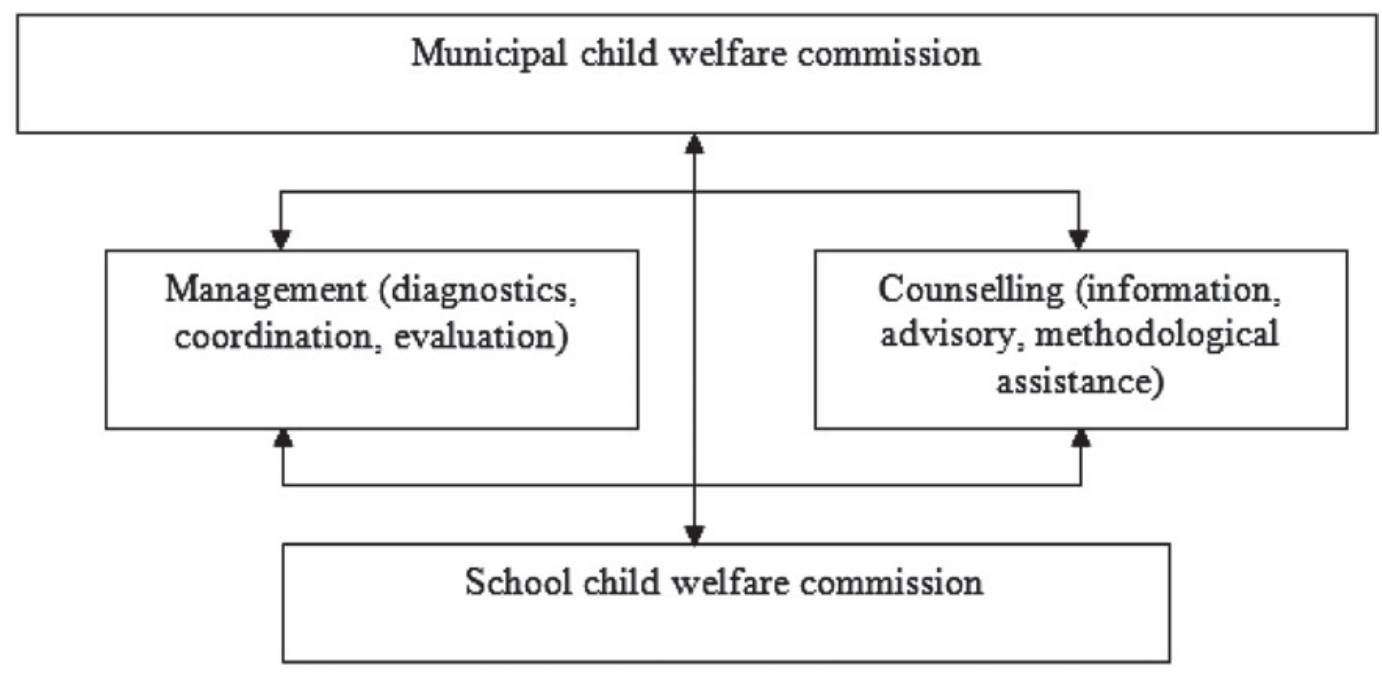

Figure 1. Functions of municipal and school child welfare commissions.

commission include "participation in various school preventive events $(\mathrm{n}=74)$; the analysis of preventive programmes and reports on preventive measures $(\mathrm{n}=86)$ ”.

Exchange of best practice examples and counselling were indicated as methodological assistance to members of the school child welfare commission: "organisation of meetings to chairmen of the school child welfare commissions, exchange of best practice examples, presentation of annual reports; organisation of workshops for the exchange of best practice examples; individual counselling". According to respondents, this assistance is provided during workshops and counselling sessions ("we organise workshops on request (at least fife workshops annually); together we take part in round table discussions and provide counselling; usually people need assistance of a psychologist or legal advice”).

According to respondents the main trends of school child welfare commissions are: education of school community $(n=104)$; prevention of law violations $(n=95)$; protection of the rights of the child $(n=96)$; development of pupils' occupational interests $(n=92)$; planning of preventive work $(n=92)$; work with pupils having behaviour problems $(n=71)$.

The aim was to identify main problems of municipal and school child welfare commissions. Members of the municipal child welfare commission related problems to gaps in the legislation $(n=42)$. They highlighted that duties of parents and legal guardians of the child for non-performance of the anticipated measures are not specified in the Law ("the Law does not stipulate responsibilities of the child's legal guardians for non-performance of the anticipated measures; parents who didn't take care of the child in the past will hardly do this in the future; usually social educators are the ones who take care of such children and parents in schools").

According to members of the municipal child welfare commission, group members lack motivation $(\mathrm{n}=24)$ since this is a voluntary work ("usually we sacrifice our main work time but have to fulfil our main duties afterwards; often the employer is not interested in our activities outside the institution; our work is not estimated/calculated"). According to respondents, payment/promotion of the chairman of the child welfare commission and/or case manager $(n=24)$ and organisation of study trips for members $(n=39)$ could ensure more effective resolution of problems. Respondents were convinced that every case needs case manager ("it is nice to see efforts of representatives of all institutions, but who will coordinate each individual case? case manager is not assigned; chairman is not obliged to coordinate every case, moreover that he/she works for free; it would be ideal to have at least a part-time worker who could coordinate and supervise all cases"). 


\section{Int. Conf. SOCIETY. HEALTH. WELFARE; Congr. of Rehabilitation Doctors of Latvia}

Members of school child welfare commissions $(n=72)$ identified similar problems as members of municipal child welfare commissions: low motivation of specialists $(n=69)$ because of a non-paid work activities; indifference of parents $(n=58)$ and lack of measures in the Law $(n=47)$. Respondents related possible problem solutions to the selection of group members and promotion measures $(\mathrm{n}=$ $71)$; involvement of exceptionally motivated group members into activity $(n=39)$; anticipation of family responsibilities for non-performance of measures $(n=72)$; preparation of methodological recommendations for members of the child welfare commission $(n=53)$.

Members of school child welfare commissions were asked about the assistance provided by the municipal child welfare commission. It was defined that usually information $(n=33)$ and counselling assistance is provided ( $\mathrm{n}=27$ members received assistance, 12 members did not). Most of all members of school child welfare commissions missed methodological assistance (the majority of respondents who applied for the above assistance didn't receive it). Especially effective assistance was related to mediation between school and other institutions ( $\mathrm{n}=42$ from 45 groups); assistance was not provided in 15 out 27 cases, although specialists did apply for the evaluation of efficiency of preventive work.

According to members of municipal and school child welfare commissions counselling of a specialist in evaluating effectiveness of the measures set forth in the Law on Minimal and Average Care of the Child is very effective measure if it is applied together with other measures ("occupational measures etc. $(\mathrm{n}=112)$; according to the majority of groups the obligation to attend day centres is not an effective measure $(\mathrm{n}=68)$, ("in small regions there are no day centres, and school specialists cannot control frequency of attendance of the child, moreover that the majority of centres are private"); obligation to study is also ineffective measure ("majority of pupils entitled to minimal measures have motivation problems").

\section{Conclusions}

1. The Law on Minimal and Average Care of the Child helps to ensure the provision of a qualified assistance to the child and his/her family, as well as a consistent development of the juvenile justice system in Lithuania.

2. Municipal child welfare commission performs control and supervisory functions. Functions of members of a school child welfare commission include community education and organisation of preventive work.

3. Problems of the municipal child welfare commission are related to absence of responsibilities to parents and child's legal guardians in the Law for non-performance of the anticipated measures. One of the main problems of school child welfare commissions is indifference of parents. Various motivation measures for work in the child welfare commission could stimulate and enhance the activity of its members.

4. It is necessary to prepare methodological recommendations for execution of the anticipated measures to members of child welfare commissions, since service providers interpret measures stipulated in the Law differently; this prevents from provision of an effective assistance.

\section{References}

[1] Berns, R.M. (2009) Vaiko socializacija. Šeima. Mokykla. Visuomenė [Socialisation of the Child. Family. School. Society]. Vilnius: UAB "Poligrafija ir informatika", 592 p.

[2] Darling-Hammond, L., McLaughlin, M. (1995) Policies that support Professional Development in an Era of Reform. Phi Delta Kappan, vol. 76 (8), p. 87-604.

[3] Europos ekonomikos ir socialiniụ reikalụ komiteto nuomonė dèl Nepilnamečių nusikalstamumo prevencijos. Kovos su nepilnamečių nusikalstamumu būdai ir nepilnamečių justicijos sistemos vaidmuo Europos Sajungoje (2006/C 110/13) [Opinion of the European Economic and Social Committee on The prevention of juvenile delinquency. Ways of dealing with juvenile 


\section{SHS Web of Conferences}

delinquency and the role of the juvenile justice system in the European Union (2006/C 110/13)]. http: //eur-lex. europa.eu/LexUriServ/LexUriServ.do?uri=0J : C : 2006:110:0075: $0082: \mathrm{LT}: \mathrm{PDF}$

[4] Germain, C.B., Gitteman, A. (1980) The Life Model of Social Work Practice. New York: Columbia University Press, p. 376.

[5] Havana Rules, 1990. http://www.pfi.org/.../united-nations-rules-for-theprotection-of-juveniles-deprived-of-their-liberty-united-nations-documentdecember-1990-en.

[6] Leliūgienè, I. (2002) Socialinè pedagogika [Social Pedagogy]. Kaunas: Technologija. Vaiko minimalios ir vidutinès priežiūros įstatymas, $2007 \mathrm{~m}$. birželio $28 \mathrm{~d}$. Valstybès žinios Nr. X-1238 [The Law on Minimal and Average Care of the Child, 28 June, 2007, State News, No X-1238].

[7] Payne, M. (2000) Teamwork in multiprofessional care. USA: Palgrave, p. 268.

[8] Riyadh Guidelines (1990) http://www.pfi.org/.../united-nations-guidelines-forthe-prevention-of-juvenile-delinquency-the-riyadh-guidelines-unitednations-document-1990-en/.

[9] Vaiko teisu konvencija [Convention of the Rights of the Child, State News, 1985, No 60-1501]. Valstybès žinios, 1985, Nr. 60, p. 1501. 